\title{
Leaf deciduousness and flowering of woody Caatinga species
}

\author{
Gabriela Kaliny de Andrade Moura ${ }^{1}$ \\ Mayara Kicia Gomes Rufino ${ }^{3}$ \\ Fernanda Kelly Gomes da Silva ${ }^{2}$ \\ Carlos Henrique Britto de Assis Prado ${ }^{3}$ \\ Dilma Maria de Brito Melo Trovão ${ }^{1 *}$ \\ ${ }^{1}$ Universidade Estadual da Paraíba, Centro de Ciências Biológicas e da Saúde \\ Departamento de Biologia, CEP 58.429-500, Campina Grande - PB, Brasil \\ ${ }^{2}$ Universidade Federal do Ceará, Fortaleza - CE, Brasil \\ ${ }^{3}$ Universidade Federal de São Carlos, Centro de Ciências Biológicas e da Saúde \\ Programa de Pós-Graduação em Ecologia e Recursos Naturais, São Carlos - SP, Brasil \\ * Autor pra correspondência \\ dilmatrovao@gmail.com
}

Submetido em 24/03/2020

Aceito para publicação em 23/11/2020

\section{Resumo}

Deciduidade foliar e floração de espécies lenhosas da Caatinga. Determinamos a distribuição (FDI), a duração (FDU) e o pico (FPE) da floração em espécies lenhosas decíduas (DE) e sempre verdes (EV) na vegetação de Caatinga usando dados da literatura. Estabelecemos possíveis relações entre a persistência da folhagem e a fenologia reprodutiva ao longo do ano. FDI indicou o número relativo de espécies produzindo flores em cada mês e FDU o número de meses que cada espécie apresentou flores. Definimos o FPE como os quatro meses consecutivos com o maior número de espécies em floração. O estresse hídrico severo provavelmente restringiu a variabilidade de FDU e FDI ao longo do ano devido à incapacidade de DE e EV sustentarem anexos reprodutivos e vegetativos simultaneamente durante o período seco. Algumas DE floresceram no período seco em uma copa livre de folhas, possivelmente devido à água acumulada no corpo da planta. A floração em EV ocorreu fora do período seco, com o FPE acontecendo durante a transição entre períodos seco-chuvoso. As EV provavelmente capturam as primeiras chuvas por todo o corpo da planta cobrindo a demanda hídrica da folhagem e dos brotos reprodutivos desdobrados antecipando a floração. A floração antecipada nas EV resultou em diferentes valores de FPE entre DE e EV.

Palavras-chave: Decíduas; Fenologia; Semiárido; Sempre-verdes

\section{Abstract}

We determined the distribution (FDI), duration (FDU), and peak (FPE) of flowering in woody deciduous (DE) and evergreen (EV) species of the Caatinga with available data in the literature. Possible relations were established between leaf persistence and reproductive phenology throughout the year. The FDI indicated the relative number of species bearing flowers in each month, and the FDU denoted the number of months each 
species showed flowers. We defined the FPE as the four consecutive months with the highest number of species in flower. DE and EV did not show significant differences in FDI and FDU, probably due to the inability to sustain reproductive and vegetative annexes of woody axes simultaneously during the dry period. Some DE species showed flowering during the dry period in a crown free of leaves. EV flow due to water accumulated inside the plant body. The blooming peak in EV during the transition between dry-rainy periods may indicate the ability to capture the first rain to cover the hydric demand of full foliage and unfolded reproductive buds anticipating the flowering, resulting in different values of FPE.

Key words: Deciduous; Evergreen; Phenology; Semiarid

\section{Introduction}

Caatinga vegetation stays in the Northeast of Brazil in the semiarid area, occupying $11 \%$ of the national territory. It is subject to high solar irradiance and potential evapotranspiration, reduced cloudiness, and low monthly relative humidity. The total yearly rainfall $(250-800 \mathrm{~mm})$ is distributed irregularly, along with 2-3 months of the year. Those environmental filters result in intense water shortage in the Caatinga area (TROVÃO et al., 2007; SILVA et al., 2014a; CARVALHO et al., 2016).

Woody species show unique functional traits in the Caatinga as a result of the interaction with water, heat, and irradiance stresses. The phenological patterns of woody species respond to those imposed environmental conditions determining the dynamics of resource use and acquisition (MORELLATO; LEITÃO FILHO, 1995; ALMEIDA; ALVES, 2000; LUCENA et al., 2015). However, the relationships between the reproductive phenology with foliage persistence and climate variables in Caatinga woody species are not known.

Leaf deciduousness is an efficient strategy to reduce potential damage caused by water stress (SILVA et al., 2014a). In the Caatinga, the total loss of foliage in deciduous (DE) occurs throughout the dry season, with foliage area renewal in the first rains (ARAÚJO; FERRAZ, 2003; BARBOSA et al., 2003). Both foliage production and flowering appear to be regulated by water availability over the years (TROVÃO et al., 2007; LIMA; RODAL, 2010; SILVA et al., 2014a).

On the other hand, woody species under the same environmental conditions of the Caatinga do not flower during the same period (BARBOSA et al., 2003).
Furthermore, studies on phenology did not separate DE and evergreen (EV) in the Caatinga (BARBOSA et al., 1989; 2003; AMORIM et al., 2009; LIMA; RODAL, 2010; SOUZA et al., 2015). Despite intense water stress, there is no consensus on the main environmental factors that determine the reproductive phenology in the Caatinga woody species (LIMA; RODAL, 2010). The climatic events were only generically related to reproductive phenology (BARBOSA et al., 1989; PEREIRA et al., 1989; MACHADO et al., 1997; GRIZ; MACHADO, 2001; AMORIM et al., 2009).

Leaf deciduousness and flowering are essential events for establishing relationships between the climate and the use of resources (BORGES; PRADO, 2014). In the present research, we tested if flowering duration, flowering distribution, and flowering peak in $\mathrm{DE}$ and $\mathrm{EV}$ woody species in the Caatinga are similar throughout the year. The relation between leaf persistence and flowering traits may uncover the strategies of each phenological group for using the resources under the stressful environment of the Caatinga.

\section{Materials and Methods}

\section{Metadata collection}

The data were collected from documentary research, using the methodology proposed by Borges and Prado (2014). The articles were found with the help of Google Scholar, Web of Science, and Capes journals, from keywords in Portuguese and English, without temporal limitation. The keywords in Portuguese and English used were: Caatinga, phenology, woody species, tree species, and leaf deciduousness. The articles containing 
data about the flowering period or leaf deciduousness were selected. The scientific names of the species have been updated according to "The Plant List" and "Flora do Brasil 2020" (Table 1).

\section{Leaf phenological groups}

After quantifying the number of species contained in the studies, sorting by leaf phenology, we classified them into deciduous (DE) and evergreen (EV). Deciduous (DE) lose all foliage during some period of the year (six to twelve months), while EV species keep the same leaf area throughout the dry and rainy seasons (BARBOSA et al., 2000; SILVA et al., 2004; SOUSA et al., 2015).

\section{Calculation of flowering variables}

We determined flowering duration (FDU) as the number of months with flowers in each species. Flowering distribution (FDI) denoted the number of species per month. Flowering peak (FPE) was calculated using the four consecutive months with the highest number of species flowering in each leaf phenological group (DE and EV).

\section{Data analysis}

The free software R, version 3.2 .2 (2014) was used. Leaf phenological groups (DE and EV) were compared using the flowering variables independently, with a significance level at $\mathrm{p}<0.05$. The Shapiro-Wilk test was applied to evaluate whether the values of FDU showed normal distribution. Subsequently, the data were submitted to the Wilcoxon-Mann-Whitney test to verify the significant difference in the average values of FDU between DE and EV. The percentage of flowering species in each month was used in the Chi-square test to check differences in flowering distribution (FDI) between DE and EV. A circular statistical analysis was performed for independent Watson-Williams samples to compare flowering Peaks (FPE). In this test, the four consecutive months with a higher incidence of flowering between species were converted to degrees, increasing by $30^{\circ}$ a month, January being $30^{\circ}$, and December $360^{\circ}$ (ZAR, 1984).

\section{Results}

Table 1 shows the flowering months of the 38-woody species of the Caatinga according to the data obtained in the available literature, and the corresponding leaf deciduousness resulting in $34 \mathrm{DE}$ and four EV species.

TABLE 1: Months with the occurrence of flowers in deciduous (DE) and evergreen (EV) woody species of Caatinga. $\mathrm{LD}=$ Leaf deciduousness. The numbers in the last column indicate the corresponding literature. Pereira et al. (1989) [1], Machado et al. (1997) [2], Kill et al. (2005) [3], Leal et al. (2007) [4], Barbosa et al. (2003) [5], Silva et al. (2008) [6], Cavalcanti et al. (2008) [7], Amorim et al. (2009) [8], Neves et al. (2010) [9], Souza et al. (2012) [10], Souza et al. (2014) [11], Teixeira et al. (2015) [12], Kill and Silva (2016) [13].

\begin{tabular}{|c|c|c|c|c|c|c|c|c|c|c|c|c|c|c|}
\hline \multirow{2}{*}{ Family/Species } & \multirow{2}{*}{ LD } & \multicolumn{12}{|c|}{ Months of the year with flowers } & \multirow{2}{*}{ Sources } \\
\hline & & $\mathbf{J}$ & $\mathbf{F}$ & M & A & $\mathbf{M}$ & $\mathbf{J}$ & $\mathbf{J}$ & $\mathbf{A}$ & $\mathbf{S}$ & $\mathbf{O}$ & $\mathbf{N}$ & D & \\
\hline \multicolumn{15}{|l|}{ Anacardiaceae } \\
\hline Myracrodruon urundeuva Allemão & $\mathrm{DE}$ & & & & & & $\mathrm{x}$ & $\mathrm{x}$ & $\mathrm{x}$ & $\mathrm{x}$ & & & & 2,5 \\
\hline Schinopsis brasiliensis Engl. & $\mathrm{DE}$ & & & & & & $\mathrm{x}$ & $\mathrm{x}$ & $\mathrm{x}$ & $\mathrm{x}$ & & & & 2 \\
\hline Spondias tuberosa Arruda & $\mathrm{DE}$ & $\mathrm{x}$ & & & & & & & $\mathrm{x}$ & $\mathrm{x}$ & $\mathrm{x}$ & $\mathrm{x}$ & $\mathrm{x}$ & 5 \\
\hline Astronium urundeuva Engl. & $\mathrm{DE}$ & $\mathrm{x}$ & & & & & & & & & & & $\mathrm{x}$ & 2,7 \\
\hline
\end{tabular}




\begin{tabular}{|c|c|c|c|c|c|c|c|c|c|c|c|c|c|c|}
\hline \multirow{2}{*}{ Family/Species } & \multirow{2}{*}{ LD } & \multicolumn{12}{|c|}{ Months of the year with flowers } & \multirow{2}{*}{ Sources } \\
\hline & & $\mathbf{J}$ & $\mathbf{F}$ & M & $\mathbf{A}$ & $\mathbf{M}$ & $\mathbf{J}$ & $\mathbf{J}$ & $\mathbf{A}$ & $\mathbf{S}$ & $\mathbf{O}$ & $\mathbf{N}$ & D & \\
\hline \multicolumn{15}{|l|}{ Annonaceae } \\
\hline $\begin{array}{l}\text { Rolliniopsis leptopetala (R.E.Fr.) } \\
\text { Saff }\end{array}$ & $\mathrm{DE}$ & $\mathrm{x}$ & $\mathrm{x}$ & $\mathrm{x}$ & & & & & & & & & $\mathrm{x}$ & 2 \\
\hline \multicolumn{15}{|l|}{ Apocynaceae } \\
\hline \multicolumn{14}{|l|}{ Burseraceae } & $1,5,8$ \\
\hline $\begin{array}{l}\text { Commiphora leptophloeos (Mart.) } \\
\text { J.B.Gillett }\end{array}$ & $\mathrm{DE}$ & $\mathrm{x}$ & $\mathrm{x}$ & $\mathrm{x}$ & & & & & & & & & $\mathrm{x}$ & 2 \\
\hline \multicolumn{15}{|l|}{ Bignoniaceae } \\
\hline $\begin{array}{l}\text { Handroanthus heptaphyllus (Vell.) } \\
\text { Mattos }\end{array}$ & $\mathrm{DE}$ & & & & & & $\mathrm{x}$ & $\mathrm{x}$ & $\mathrm{x}$ & $\mathrm{x}$ & $\mathrm{x}$ & & & 8,11 \\
\hline \multicolumn{15}{|l|}{ Boraginaceae } \\
\hline Cordia oncalyx Allemão & $\mathrm{DE}$ & & & $\mathrm{x}$ & $\mathrm{x}$ & $\mathrm{x}$ & $\mathrm{x}$ & $\mathrm{x}$ & $\mathrm{x}$ & $\mathrm{x}$ & $\mathrm{x}$ & & & 1,11 \\
\hline \multicolumn{15}{|l|}{ Capparaceae } \\
\hline Cynophalla flexuosa (L.) J.Presl & $\mathrm{EV}$ & $\mathrm{x}$ & $\mathrm{x}$ & $\mathrm{x}$ & $\mathrm{x}$ & $\mathrm{x}$ & & & & & & $\mathrm{x}$ & $\mathrm{x}$ & 2,8 \\
\hline \multicolumn{15}{|l|}{ Celastraceae } \\
\hline Monteverdia rigida (Mart.) Biral & EV & $\mathrm{x}$ & $\mathrm{x}$ & $\mathrm{x}$ & & & & & & & $\mathrm{x}$ & $\mathrm{x}$ & $\mathrm{x}$ & 5 \\
\hline \multicolumn{15}{|l|}{ Combretaceae } \\
\hline Combretum leprosum Mart. & $\mathrm{DE}$ & & $\mathrm{x}$ & $\mathrm{x}$ & $\mathrm{x}$ & $\mathrm{x}$ & $\mathrm{x}$ & & & & $\mathrm{x}$ & $\mathrm{x}$ & $\mathrm{x}$ & 8 \\
\hline \multicolumn{15}{|l|}{ Euphorbiaceae } \\
\hline $\begin{array}{l}\text { Cnidoscolus bahianus (Ule) } \\
\text { Pax \& K.Hoffm. }\end{array}$ & $\mathrm{DE}$ & & & $\mathrm{x}$ & $\mathrm{x}$ & $\mathrm{x}$ & $\mathrm{x}$ & $\mathrm{x}$ & $\mathrm{x}$ & $\mathrm{x}$ & $\mathrm{x}$ & $\mathrm{x}$ & & 3,4 \\
\hline Cnidoscolus quercifolius Pohl & $\mathrm{DE}$ & $\mathrm{x}$ & $\mathrm{x}$ & $\mathrm{x}$ & & & & & & $\mathrm{x}$ & $\mathrm{x}$ & $\mathrm{x}$ & $\mathrm{x}$ & 4,12 \\
\hline Cnidoscolus urens (L.) Arthur & $\mathrm{DE}$ & $\mathrm{x}$ & & & & & & & & & & & $\mathrm{x}$ & 4 \\
\hline Croton campestris A.St.-Hil. & $\mathrm{DE}$ & $\mathrm{x}$ & & & & & & & & & & & $\mathrm{x}$ & 4 \\
\hline Croton conduplicatus Kunth & $\mathrm{DE}$ & $\mathrm{x}$ & $\mathrm{x}$ & $\mathrm{x}$ & & & & & & & & & $\mathrm{x}$ & 10 \\
\hline Croton sonderianus Müll.Arg. & $\mathrm{DE}$ & & $\mathrm{x}$ & $\mathrm{x}$ & & & & & & & $\mathrm{x}$ & $\mathrm{x}$ & & $1,2,4,10$ \\
\hline Jatropha mollissima (Pohl) Baill. & $\mathrm{DE}$ & & $\mathrm{x}$ & $\mathrm{x}$ & $\mathrm{x}$ & $\mathrm{x}$ & & & $\mathrm{x}$ & $\mathrm{x}$ & $\mathrm{x}$ & & & $8,9,10,12$ \\
\hline Jatropha mutabilis (Pohl) Baill. & $\mathrm{DE}$ & $\mathrm{x}$ & $\mathrm{x}$ & $\mathrm{x}$ & & & & & & & & & & 9 \\
\hline Jatropha gossypiifolia L. & $\mathrm{DE}$ & $\mathrm{x}$ & & & & & & & & & & & $\mathrm{x}$ & 4 \\
\hline Manihot glaziovii Müll.Arg. & $\mathrm{DE}$ & $\mathrm{x}$ & $\mathrm{x}$ & $\mathrm{x}$ & & & & $\mathrm{x}$ & $\mathrm{x}$ & $\mathrm{x}$ & $\mathrm{x}$ & $\mathrm{x}$ & $\mathrm{x}$ & 2,11 \\
\hline \multicolumn{15}{|l|}{ Fabaceae } \\
\hline $\begin{array}{l}\text { Amburana cearensis (Allemão) } \\
\text { A.C.Sm. }\end{array}$ & $\mathrm{DE}$ & & & & & $\mathrm{x}$ & $\mathrm{x}$ & $\mathrm{x}$ & & & & & & 2,8 \\
\hline $\begin{array}{l}\text { Anadenanthera colubrina (Vell.) } \\
\text { Brenan }\end{array}$ & $\mathrm{DE}$ & $\mathrm{x}$ & $\mathrm{x}$ & $\mathrm{x}$ & & & & & & & & $\mathrm{x}$ & $\mathrm{x}$ & $2,6,8,13$ \\
\hline $\begin{array}{l}\text { Anadenanthera colubrina var. cebil } \\
\text { (Griseb.) Altschul }\end{array}$ & $\mathrm{DE}$ & & & $\mathrm{x}$ & $\mathrm{x}$ & $\mathrm{x}$ & & & & & & & & 5,8 \\
\hline Caesalpinia ferrea C. Mart. & $\mathrm{DE}$ & & & $\mathrm{x}$ & $\mathrm{x}$ & $x$ & $x$ & $x$ & $\mathrm{x}$ & $\mathrm{x}$ & $\mathrm{x}$ & & & 2,8 \\
\hline
\end{tabular}




\begin{tabular}{|c|c|c|c|c|c|c|c|c|c|c|c|c|c|c|}
\hline \multirow{2}{*}{ Family/Species } & \multirow{2}{*}{ LD } & \multicolumn{12}{|c|}{ Months of the year with flowers } & \multirow{2}{*}{ Sources } \\
\hline & & $\mathbf{J}$ & $\mathbf{F}$ & $\mathbf{M}$ & A & M & $\mathbf{J}$ & $\mathbf{J}$ & $\mathbf{A}$ & $\mathbf{S}$ & $\mathbf{O}$ & $\mathbf{N}$ & D & \\
\hline Caesalpinia pyramidalis Tul. & $\mathrm{DE}$ & $\mathrm{x}$ & $\mathrm{x}$ & $\mathrm{x}$ & $\mathrm{x}$ & & & & & & & $\mathrm{x}$ & $\mathrm{x}$ & $2,5,8,11$ \\
\hline $\begin{array}{l}\text { Senna spectabilis var. excelsa } \\
\text { (Schrad.) H.S.Irwin \& Barneby }\end{array}$ & $\mathrm{DE}$ & & & $\mathrm{x}$ & $\mathrm{x}$ & & & & & & & & & 5 \\
\hline Bauhinia cheilantha (Bong.) Steud. & $\mathrm{DE}$ & $\mathrm{x}$ & $\mathrm{x}$ & $\mathrm{x}$ & & & & & & & & & & 2 \\
\hline Dipteryx odorata (Aubl.) Willd. & $\mathrm{DE}$ & & & & & & & $\mathrm{x}$ & $\mathrm{x}$ & $\mathrm{x}$ & & & & 11 \\
\hline Mimosa acutistipula Benth. & $\mathrm{DE}$ & $\mathrm{x}$ & $\mathrm{x}$ & $\mathrm{x}$ & $\mathrm{x}$ & & & $\mathrm{x}$ & $\mathrm{x}$ & $\mathrm{x}$ & & & & 1,8 \\
\hline Mimosa caesalpiniifolia Benth. & $\mathrm{DE}$ & & & $\mathrm{x}$ & $\mathrm{x}$ & $\mathrm{x}$ & & & & & & & & 1 \\
\hline $\begin{array}{l}\text { Parapiptadenia zehntneri (Harms } \\
\text { M.P.Lima \& H.C.Lima }\end{array}$ & $\mathrm{DE}$ & $\mathrm{x}$ & $\mathrm{x}$ & & & & & & & & & & $\mathrm{x}$ & 2 \\
\hline $\begin{array}{l}\text { Chloroleucon foliolosum (Benth. } \\
\text { G.P.Lewis }\end{array}$ & $\mathrm{DE}$ & & $\mathrm{x}$ & $\mathrm{x}$ & $\mathrm{x}$ & & & & & & $\mathrm{x}$ & $\mathrm{x}$ & & 8 \\
\hline \multicolumn{15}{|l|}{ Malvaceae } \\
\hline $\begin{array}{l}\text { Pseudobombax marginatum } \\
\text { (A.St.-Hil.) A. Robyns }\end{array}$ & $\mathrm{DE}$ & & & & $\mathrm{x}$ & $\mathrm{x}$ & $\mathrm{x}$ & $\mathrm{x}$ & $\mathrm{x}$ & $\mathrm{x}$ & $\mathrm{x}$ & & & 2,11 \\
\hline Helicteres baruensis Jacq. & $\mathrm{DE}$ & $\mathrm{x}$ & $\mathrm{x}$ & $\mathrm{x}$ & & & & & & & & & & 2 \\
\hline \multicolumn{15}{|l|}{ Rhamnaceae } \\
\hline Ziziphus joazeiro Mart. & $\mathrm{EV}$ & $\mathrm{x}$ & $\mathrm{x}$ & & & & & & & & & $\mathrm{x}$ & $\mathrm{x}$ & $1,2,5$ \\
\hline \multicolumn{15}{|l|}{ Sapotaceae } \\
\hline $\begin{array}{l}\text { Sideroxylon obtusifolium (Roem. \& } \\
\text { Schult.) T.D.Penn. }\end{array}$ & $\mathrm{EV}$ & $\mathrm{x}$ & $\mathrm{x}$ & $\mathrm{x}$ & & & & & & $\mathrm{x}$ & $\mathrm{x}$ & $\mathrm{x}$ & $\mathrm{x}$ & 5 \\
\hline
\end{tabular}

Deciduous (DE) and evergreen (EV) species presented FPE between November and March, with significant differences $(p=0.02$; Figure 1$)$. The months with the most considerable number of flowering species were December (23), January (22), February (21), and March (23). On the other hand, the months of May (11), June (11), and July (12) showed the lowest number of species with flowers. Figure 2 shows the percentage of flowering species in each phenological group throughout the year concerning the total of the species analyzed. Both DE and EV presented the highest number of flowers between December and
February. However, EV had a higher number of months with flowers, even with a reduced number of species (4) compared to DE (34). In DE, there is a relationship between flowering and seasonality, as $50-80 \%$ of plants bloom between October and March, coinciding with the rainy season, the duration of which depends on the location in the Caatinga area. The remaining months of the year are usually the dry period, lasting longer or resulting in years free of rainfall, depending on the dominant climatic processes (SOUZA FILHO; MOURA, 2006; MARENGO et al., 2011). 
FIGURE 1: Representation of the relative number of woody species with the flower in deciduous (DE, $34 \mathrm{species)}$ and evergreen (EV, 4 species) across the year in Caatinga vegetation. The period with the most considerable number of flowering species was between December-March. The number of flanking the bars indicates how many species with flowers in every leaf phenological group.

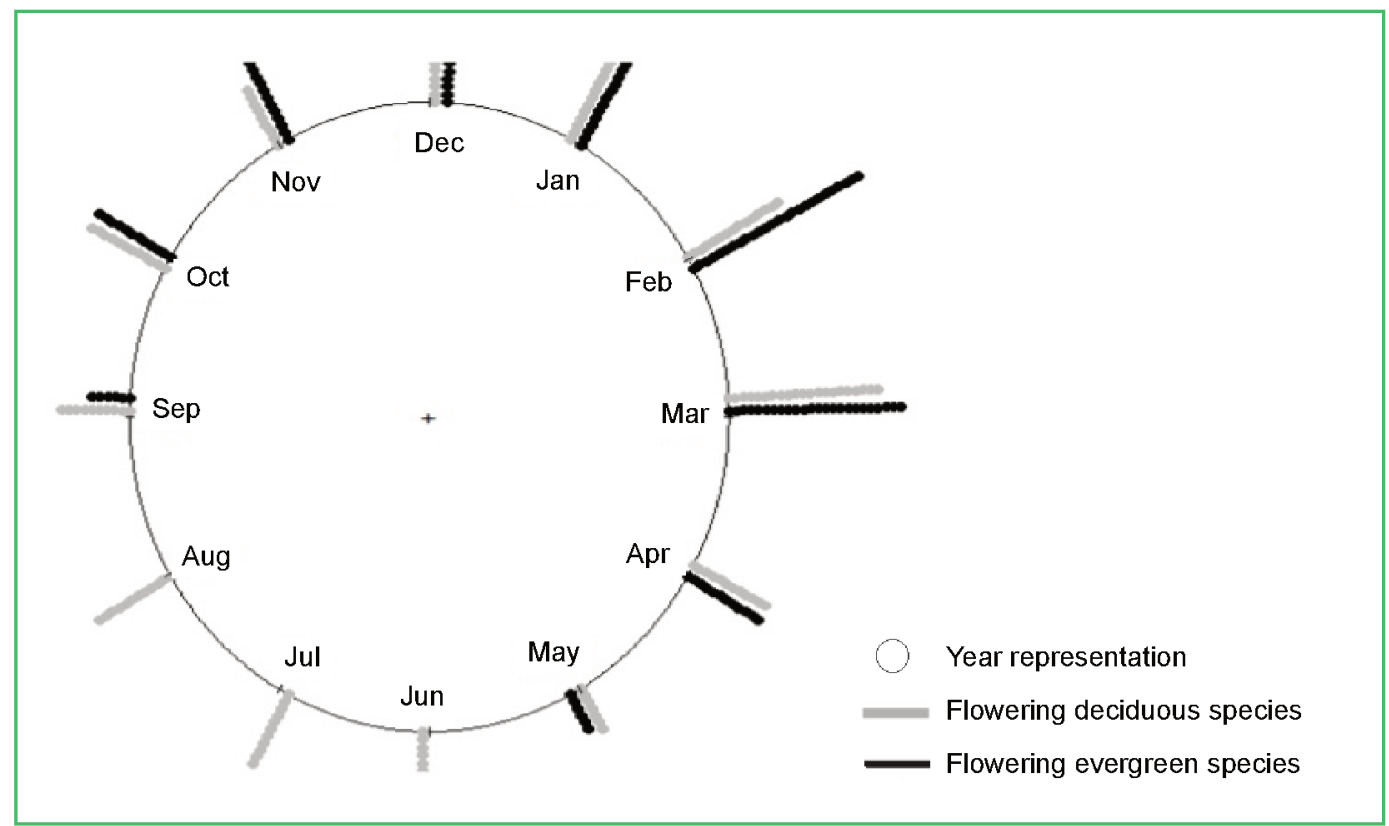

FIGURE 2: Percentage of Caatinga woody species with flowers throughout the year about the total of the studied species (34 deciduous and four evergreens). RAIN = rainy period; DRY = dry period; TR= period of transition.

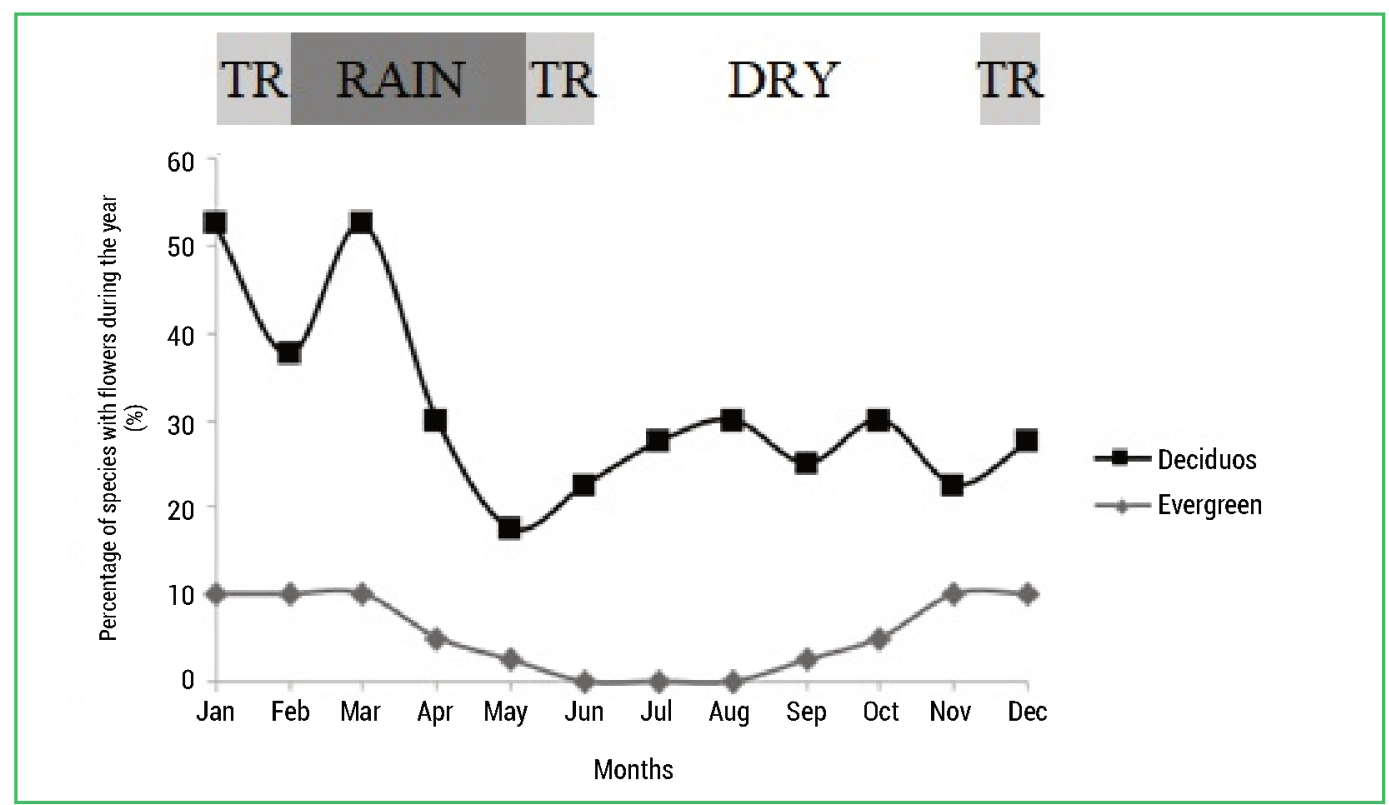


The Wilcoxon-Mann-Whitney test showed no significant difference $(p=0.05)$ between the mean values of FDU between leaf phenological groups. Besides, the Chi-square test also did not output $(p=0.45)$ significant differences between DE and EV about FDI.

\section{Discussion}

Our results showed the flowering of most of the woody Caatinga species occurring from October to March, which coincides with the transition from the dry to the rainy period, reaching the middle of the rainy period (MARENGO et al., 2011). This result is partially in agreement with those found for the Caatinga vegetation indicating flowering principally in the rainy season (BARBOSA et al., 2003; AMORIM et al., 2009; LIMA; RODAL, 2010; SOUZA et al., 2014; AMORIM et al., 2009). Our results pointed to some convergence with that recorded for savanna formations, such as the Brazilian Cerrado (BORGES; PRADO, 2014; PILON et al., 2015). According to Borges and Prado (2014), the flowering of $\mathrm{DE}$ and $\mathrm{EV}$ Cerrado tree species is concentrated during the transition from the dry to the rainy period (AugustNovember), which means that the production of flowers for most species does not depend exclusively on soil water availability. The dry period in the Cerrado is concise, differing from the Caatinga, in which it can last for more than six months or even years (SOUZA FILHO, 2003; MARENGO et al., 2011; PRADO, 2012). In dry Mexican rainforests, whose annual rainfall varies between 600 and $1400 \mathrm{~mm}$, Valdez-Hernández (2015) has identified that flowering peaks occurred in two main periods: in the dry season (March-May) and principally at the end of the rainy season (October-November). In the dry forests of Ghana, whose average annual rainfall is $1100 \mathrm{~mm}, 78 \%$ of the species show flowers in the rainy season (LIEBERMAN, 1982). Hence, in seasonal climates, flowering occurs preferentially in rainy and during the transitions of wetdry periods, induced by the first rainfall and changes in photoperiod and temperature (KUSHWAHA et al., 2011).

According to Lima and Rodal (2010), some Caatinga species do not respond primarily to rainfall to initiate their phenophases. Analyzing 19 species, these authors identified six that started vegetative and reproductive phenophases during the dry period. Those six species had low wood density $\left(<0.55 \mathrm{~g} / \mathrm{cm}^{3}\right)$ and are capable of storing large amounts of water (110 to $271 \%$ of the dry weight of the wood). Therefore, irrespective of the source of water, in soil or accumulated inside the plant body, water availability seems to be a pivotal factor to initiate flowering in the Caatinga.

The non-difference in the FDU between the DE and EV Caatinga species diverges from other vegetation under seasonal climate, with EV retaining flowers for a longer period than DE (BORGES; PRADO, 2014; LACERDA et al., 2018). The persistence of foliage throughout the year is not a strategy for acquiring air space and resources selected for the vast majority of woody species in the Caatinga. The number of EV in the Caatinga is meager compared to that of DE species (SILVA et al., 2014b). About $90 \%$ of the species mentioned in the literature and used in this study are DE (Table 1). The persistence of annexed organs throughout the year (even as buds with the organ in pre-formation) in the woody axes of the crown is strongly limited or absent. Therefore, the impermanence of annexed organs in the dry period is related to desiccation avoidance.

Climatic factors such as evaporative air demand and water availability in the soil conditioned by precipitation (SILVA et al., 2014a) impose limits for the maintenance of flowers on the woody axes, irrespective of the foliage habit in the 38 woody species studied. The critical water stress in the Caatinga does not allow for much variation in reproductive phenology, resulting in similarities concerning distribution and flowering duration between DE and EV (Table 1). The DE and EV Caatinga species studied are unable to meet the water demand for distinct persistent attachments (flowers and leaves) on the woody axes throughout the year. Water storage capacity in the aerial or underground part is significantly limited. Even the few species considered EV cannot meet the water demand beyond foliage during the dry period. Hence, EV are unable to produce flowers initially and in the middle of the driest period (June, July, and August). Thus, the simultaneous maintenance of foliage and flowers in the driest period is practically unfeasible in the DE and EV species studied. 
However, the peak of flowering in DE can be more easily modulated without foliage competition for the little water available in the soil or accumulated inside the plant body. Even in the driest period (May-December), about $25 \%$ of DE supported flowers (Figure 2). Thus, DE species are capable of flowering throughout the year. In August, $30 \%$ of the DE species were in bloom, while none were EV. The ability of DE to produce flowers during the dry period may avoid more active herbivores during the rainy period (AIDE; ANGULO-SANDOVAL, 1997; SILVA et al., 2009). Besides, flowering during the dry period makes flowers more visible to potential pollinators (MANTOVANI; MARTINS, 1988). With the foliage partially absent or free of leaves, the DE species can sustain flowering more independently of soil water availability than the EV. However, the more favorable water balance in DE trees, due to the absence of a leaf area, cannot significantly alter the FDU and FDI.

The difference between DE and EV concerning the FPE is due to the anticipation of the latter. The FPE of EV species occurred only during the transition from the dry to the rainy period, from November to February. How can EV species sustain flowering under short and unpredictable water availability in the period transition? With a full area of foliage and under severe water stress, the evergreen species may unfold reproductive buds only after the first rains. This is risky since there is no precipitation during several years in the Caatinga area (SILVA et al., 2014a). In the literature, it is noted that some evergreen cannot bloom during the entire year, such as Erythroxylum pungens (AMORIM et al., 2009) and Schinopsis glabra (MACHADO et al., 1997). This may happen during the absence of rain, with little water availability in the plant body, besides the hydric demand of the full leaf area at the peak of the dry season. Therefore, EV species probably have an efficient root system to capture the first rains, or even some mechanism to transport water quickly from wet foliage and woody branches to reproductive buds.

The severe water stress in the Caatinga restricts the variability of flowering duration and flowering distribution throughout the year in DE and EV woody species. The leaf phenological groups did not show significant differences concerning those flowering attributes due to the inability to sustain reproductive and vegetative annexes of woody axes simultaneously during the dry period. Some DE showed flowering in the dry period in a crown free of leaves. EV flowering occurred outside the dry period. Flowering during the dry season in DE may happen due to water accumulated inside the plant body. The blooming peak in EV during the transition from the dry to the wet period indicates the ability to capture the first rains, covering the hydric demand of full foliage and unfolded reproductive buds, anticipating the flowering of DE. This results in a different peak of flowering between DE and EV.

\section{Acknowledgments}

The authors would like to thank the Postdoctoral Program of the Federal University of São Carlos and the postgraduate program in Ecology and Conservation of the State University of Paraiba.

\section{References}

AIDE M.; ANGULO-SANDOVAL, P. The effect of dry season irrigation on leaf phenology and the implications for herbivory in a tropical understory community. Caribbean Journal of Science, Mayagüez, v. 33, p. 142-149, 1997.

ALMEIDA, E. M.; ALVES, M. A. S. Fenologia de Psychotria nuda e $P$. brasiliensis (Rubiaceae) em uma área de Floresta Atlântica do sudeste do Brasil. Acta Botanica Brasilica, Belo Horizonte, v. 14, p. 335-346, 2000.

AMORIM, I. L.; SAMPAIO, E. V. S. B.; ARAÚJO, E. L. Fenologia de espécies lenhosas da Caatinga do Seridó, RN. Revista Árvore, Viçosa, v. 33, p. 491-499, 2009.

ARAÚJO, E. L.; FERRAZ, E. M. N. Processos ecológicos mantenedores da diversidade vegetal na Caatinga: estado atual do conhecimento. In: CLADINO-SALES, V. (Ed.). Ecossistemas brasileiros: manejo e conservação. Fortaleza: Expressão Gráfica, 2003. p. 115-128.

BARBOSA, D. C. A.; ALVES, J. L. H.; PRAZERES, S. M.; PAIVA, A. M. A. Dados fenológicos de 10 espécies arbóreas de uma área de Caatinga (Alagoinha - PE). Acta Botanica Brasilica, Belo Horizonte, v. 3, n. 2, p. 109-117, 1989.

BARBOSA, D. C. A; BARBOSA, M. C. A.; LIMA, L. C. M. Fenologia de espécies lenhosas da Caatinga. In: LEAL, I. R.; TABARELLI, M.; SILVA, J. M. C. (Ed.). Ecologia e conservação da Caatinga. Recife, Universitária UFPE, 2003. p. 657-693.

BARBOSA, D. C. A.; NOGUEIRA, R. J. M. C.; MELO FILHO, P. A. Comparative studies of growth in three species of Caatinga submitted to water stress. Phyton, Buenos Aires, v. 69, p. 45-50, 2000 . 
BORGES, M. P.; PRADO, C. H. B. A. Relationships between leaf deciduousness and flowering traits of woody species in the Brazilian neotropical savanna. Flora-Morphology, Distribution, Functional Ecology of Plants, Freiberg, v. 209, n. 1, p. 73-80, 2014.

CARVAlHO, E. C. D.; MARTINS, F. R.; OLIVEIRA, R. S.; SOARES, A. A.; ARAÚJO, F. S. Why is liana abundance low in semiarid climates? Austral Ecology, Alice Springs, v. 41, n. 5, p. 559-571, 2016.

CAVALCANTI, N. de B.; DE RESENDE, G. M.; BRITO, L. T. de L. Fenologia reprodutiva do umbuzeiro (Spondias tuberosa Arruda). In: SIMPÓSIO BRASILEIRO SOBRE UMBU, CAJÁ E ESPÉCIES AFINS, 2008, Recife. Anais... Recife: IPA; Embrapa Agroindústria Tropical; UFRPE, 2008. Versão eletrônica.

GRIZ, L. M. S; MACHADO, I. C. S. Fruiting phenology and seed dispersal syndromes in Caatinga, a tropical dry forest in the northeast of Brazil. Journal of Tropical Ecology, Winchelsea, v. 17, n. 2, p. 303-321, 2001.

KILL, L. H. P.; DIAS, C. V. T.; SOUZA, A. S. Fenologia de Schinopsis brasiliensis Engl. na Reserva Legal do Projeto Salitre, Juazeiro-BA. In: CONGRESSO NACIONAL DE BOTÂNICA, 56, 2005, Curitiba. Resumos... Curitiba: SBB: UFPR, 2005. 1 CDROM.

KILL, L. H. P.; SILVA, T. A. Fenologia e biologia floral de Anadenanthera colubrina (Vell.) Brenan (Fabaceae) no Município de Petrolina, PE. Petrolina: Embrapa Semiárido, 2016. $25 \mathrm{p}$.

KUSHWAHA, C. P.; TRIPATHI, S. K.; SINGH, K. P. Tree specific traits affect flowering time in Indian dry tropical forest. Plant Ecology, Dordrecht, v. 212, n. 6, p. 985-998, 2011.

LACERDA, D. M. A.; ROSSATTO, D. R.; RIBEIRO-NOVAES, E. K. M. D.; ALMEIDA, J. R. E. B. Reproductive phenology differs between evergreen and deciduous species in a Northeast Brazilian savanna. Acta Botanica Brasilica, Belo Horizonte, v. 32, n. 3, p. 367-375, 2018.

LEAL, I. R.; PERINI, M. A.; CASTRO, C. C. Estudo fenológico de espécies de Euphorbiaceae em uma área de Caatinga. In: CONGRESSO DE ECOLOGIA DO BRASIL, VIII, 2007, Caxambu. Anais... Caxambu: SEB, 2007. Disponível em: <http:// www.seb-ecologia.org.br/revistas/indexar/anais/viiiceb/pdf/1143. pdf $>$.

LIEBERMAN, D. D. Seasonality and phenology in a dry tropical forest in Ghana. Journal of Ecology, London, v. 70, n. 3, p. 791806, 1982.

LIMA, A. L. A.; RODAL, M. J. N. Phenology and wood density of plants growing in the semi-arid region of northeastern Brazil. Journal of Arid Environments, London, v. 74, n. 11, p. 1363$1373,2010$.

LUCENA, I. C.; LEITE, M. B.; MATOS, D. M. S. A deciduidade foliar indica a vulnerabilidade de espécies lenhosas ao fogo. Revista Árvore, Viçosa, v. 39, n. 1, p. 59-68, 2015.

MACHADO, I. C. S.; BARROS, L. M.; SAMPAIO, E. V. S. B. Phenology of Caatinga species at Serra Talhada-PE, Northeastern Brazil. Biotropica, Malden, v. 29, n. 1, p. 57-68, 1997.

MANTOVANI, W.; MARTINS, F. R. Variações fenológicas das espécies do cerrado da Reserva Biológica de Moji Guaçu, estado de São Paulo. Revista Brasileira de Botânica, v. 11, p. 101-112, 1988.

MARENGO, J. A.; ALVES, L. M.; BESERRA, E. A.; LACERDA, F. F. Variabilidade e mudanças climáticas no semiárido brasileiro. In: MEDEIROS, S. S.; GHEYI, H. R; GALVÃO, C. O.; PAZ, V. P. S. (Org.). Recursos hídricos em regiões áridas e semiáridas. Campina Grande: INSA, 2011. p. 383-422.

MOREllato, P. C.; LEITÃO-FILHO, H. F. Ecologia e preservação de uma floresta tropical urbana: Reserva de Santa Genebra. Campinas: Editora da UNICAMP, 1995. 136 p.

NEVES, E. L.; FUNCH, L. S.; VIANA, B. F. Comportamento fenológico de três espécies de Jatropha (Euphorbiaceae) da Caatinga, semi-árido do Brasil. Revista Brasileira de Botânica, São Paulo, v. 33, n. 1, p. 155-166, 2010.

PEREIRA, R. M. A.; ARAÚJO-FILHO, J. A.; LIMA, R. V.; PAUlinO, F. D. G; LIMA, A. O. N.; ARAÚJO, Z. B. Estudos fenológicos de algumas espécies lenhosas e herbáceas da Caatinga. Revista Ciência Agronômica, Fortaleza, v. 20, n. 1, p. 11-20, 1989.

PILON, N. A. L.; UDULUTSCH, R. G.; DURIGAN, G. Phenological patterns of 111 Cerrado species under cultivation. Hoehnea, São Paulo, v. 42, n. 3, p. 425-443, 2015.

PRADO, D. E. Seasonally dry forests of tropical South America: from forgotten ecosystems to a new phytogeographic unit. Edinburg Journal of Botany, Edinburg, v. 57, p. 437-461, 2012.

SOUZA, B. C.; OLIVEIRA, R. S.; ARAÚJO, F. S.; LIMA, A. L. A.; RODAL, M. J. N. Divergências funcionais e estratégias de resistência à seca entre espécies decíduas e sempre verdes tropicais. Rodriguésia, Rio de Janeiro, v. 66, n. 1, p. 21-32, 2015.

SOUZA, D. N. N.; CAMACHO, R. G. V.; MELO, J. I. M.; ROCHA, L. N. G.; SILVA, N. F. Estudo fenológico de espécies arbóreas nativas em uma unidade de conservação de Caatinga no Estado do Rio Grande do Norte, Brasil. Biotemas, Florianópolis, v. 27, n. 2, p. 31-42, 2014.

SOUZA, R. de C.; KIILL, L. H. P.; ARAÚJO, J. L. P. Fenologia de espécies nativas da Caatinga de potencial medicinal na região de Petrolina, PE. In: JORNADA DE INICIAÇÃO CIENTÍFICA DA EMBRAPA SEMIÁRIDO, 7; JORNADA DE INICIAÇÃO CIENTÍFICA DA FACEPE/UNIVASF, 1, 2012, Petrolina. Anais... Petrolina: Embrapa Semiárido, 2012. Versão eletrônica.

SOUZA FILHO, F. A. Variabilidade e mudança climática nos semiáridos brasileiros. In: TUCCI, C. E. M.; BRAGA, B. (Org.). Clima e recursos hídricos no Brasil. Porto Alegre: ABRH, 2003. p. 77 111.

SOUZA FILHO, F. A.; MOURA, A. D. Memórias do seminário natureza e sociedade nos semi-áridos. Fortaleza: FUNCEME, 2006. 332 p.

SILVA, A. M. L.; LOPES, S. F.; VITORIO, L. A. P.; SANTIAGO, R. R.; MATTOS, E. A.; TROVÃO, D. M. Plant functional groups of species in semiarid ecosystems in Brazil: wood basic density and SLA as an ecological indicator. Brazilian Journal of Botany, São Paulo, v. 37, n. 3, p. 229-237, 2014a.

SILVA, E. C.; NOGUEIRA, R. J. M. C.; AZEVEDO NETO, A. D.; BRITO, J. Z.; CABRAL, E. L. Aspectos ecofisiológicos de dez espécies em uma área de Caatinga no município de Cabaceiras, Paraíba, Brasil. Iheringia Série Botânica, Porto Alegre, v. 59, n. 2, p. 201-206, 2004. 
SILVA, F. K. S.; LOPES, S. F.; LOPEZ, L. C. S.; MELO, J. I. M; TROVÃO, D. M. B. M. Patterns of species richness and conservation in the Caatinga along elevational gradients in a semiarid ecosystem. Journal of Arid Environments, London, v. 110, p. 47-52, 2014 b.

SILVA, J. O.; JESUS, F. M.; FAGUNDES, M.; FERNANDES, G. W. Esclerofilia, taninos e insetos herbívoros associados a Copaifera lagsdorffii Desf. (Fabaceae: Caesalpinioideae) em área de transição Cerrado-Caatinga no Brasil. Austral Ecology, Alice Springs, v. 19, n. 3, p. 197-206, 2009.

SILVA, T. A.; KILL, L. H. P.; ARAÚJO, J. L. P.; ROCHA, A. M. M. Fenologia de Anadenanthera colubrina (Leguminosae) em Petrolina-PE. In: JORNADA DE INICIAÇÃO CIENTÍFICA DA EMBRAPA SEMI-ÁRIDO, 3, 2008, Petrolina. Anais... Petrolina: Embrapa Semi-Árido, 2008. Versão eletrônica.

TEIXEIRA, M. J.; ARAÚJO, J. L. P.; KILL, L. H. P. Fenologia reprodutiva de duas espécies de Cnidosculus na região de Petrolina, PE. In: JORNADA DE INICIAÇÃO CIENTÍFICA DA EMBRAPA SEMIÁRIDO, 7; JORNADA DE INICIAÇÃO CIENTÍFICA DA FACEPE/UNIVASF, 1, 2012, Petrolina. Anais... Petrolina: Embrapa Semiárido, 2012. 1 CD-ROM. (Embrapa Semiárido. Documentos, 248).
TROVÃO, D. M. B. M.; FERNANDES, P. D.; ANDRADE, L. A.; DANTAS NETO, J. Variações sazonais de aspectos fisiológicos de espécies da Caatinga. Revista Brasileira de Engenharia Agrícola e Ambiental, Campina Grande, v. 11, p. 307-311, 2007.

VALDEZ-HERNÁNDEZ, M. Vegetative and reproductive plant phenology. In: ISLEBE, G.; CALMÉ, S.; LEÓN, J.; SCHMOK, B. (Ed.). Biodiversity and conservation of the Yucatan Peninsula, Mexico. Cham: Springer International Publishing Switzerland, 2015. p. 57-96.

ZAR, J. H. Biostatistical analysis. Vol. III. New Jersey: Prentice Hall, 1984. 718 p. 